\title{
EPISTEMOLOGY - AN ISLAMIC PERSPECTIVE
}

\author{
M. Azram \\ Department of Science, Faculty of Engineering \\ International Islamic University Malaysia \\ PO Box 10, Kuala Lumpur 50728, Malaysia.
}

azram50@hotmail.com

\begin{abstract}
Since man is the vicegerent of God in this world. And in order to enable him to fulfill his responsibilities (of his vicegerency), God has endowed man with the potentials of creative \& conceptual knowledge. It becomes incumbent upon him to mould knowledge in the framework provided by Islam. Thus all types of knowledge whether it is Natural Science, Social Science or even Pure Science, should be understood with the aim to establish an Islamic System. In this paper we will discuss the background of epistemology, different areas of epistemology-like source, types (revealed and derived), elements in Islam, principles (Unity of Allah, unity of creation, and unity of thoughts) and limitations.
\end{abstract}

ABSTRAK: Manusia merupakan khalifah Allah di muka bumi ini. Agar manusia dapat menjalankan tugasnnya (sebagai khalifah), Allah telah memperkenankan manusia dengan kebolehan berkreatif dan berfikir. Manusia diwajibkan keatasnya untuk mempergunakan ilmu seperti yang dirangkakan dalam agama Islam. Dengan itu, segala jenis ilmu sama ada Sains Semula Jadi, Sains Sosial atau pun Sains Tulen, perlu difahami dengan tujuan membentuk Sistem Islam. Kertas ini mengkaji latar belakang epistemologi, pelbagai sumber ilmu yang berbeza, jenis (yang didedahkan dan diterbitkan), elemen dalam Islam, prinsip (Keesaan Allah, keesaan kewujudan dan keharmonian pemikiran) dan batasannya.

\section{INTRODUCTION}

Epistemology, (which comes from the Greek word episteme) inquires into the nature of knowledge and justification of belief. Indeed, many writers prefer to use the label "The theory of knowledge", "Epistemology, however has an advantage of being a philosophical term of art, whereas the theory of knowledge could also apply to the investigators of sociologists of knowledge and historians of ideas", for example [1].

'Knowledge' falls short of expressing all the aspects of 'ilm. Knowledge in the Western world means information about something, divine or corporeal, while 'ilm is an all-embracing term covering theory, action and education [2].

Naquib al Attas had once made a very interesting observation. He noted that, "All wisdom is knowledge but all knowledge is not wisdom." Sometimes what we assume knowledge to be, is in real only the contemplation of man. The more this contemplation becomes consolidated with facts, the more it comes near to Truth, Wisdom. Therefore Wisdom can be considered the final stage of man's contemplation, which could be according to Qur' an, either, 'ilm al - yaqin' (Q:120:5), 'ain al yaqin'(Q:120:7), or 'haqqul yaqin' (Q:69:51). Hence the difference between Wisdom and Knowledge could be considered as the progress of human thought'. 
The commencement of Human thought is 'raib' (fantasy), (Q:9:25), and the end is yaqin (certainty) (Q:120:5\&7). The beginning of this journey is aided by 'ta'wil' (interpretation). However, it should be done by those who have a firm ground in matters of knowledge; those, who are considered the people of understanding.

In this paper therefore, the different areas of epistemology - like the source, types, and principles of knowledge will be discussed, to get a brief idea of the philosophical topic.

\section{SOURCE OF KNOWLEDGE}

The Islamic conception of the sources of knowledge differs from the conception of materialistic atheists; which makes existence their only source and cannot conceive of a methodology of knowledge except that by which the realities of the physical universe became known. It also differs from the other religious metaphysical conceptions. The pivotal difference between Islamic concept and these other systems is that the latter establishes proofs from the observable universe for its claim that there is a second source of knowledge, i.e. revelation, while the materialists deny this reality, which is indicated by the source of knowledge they acknowledge, which places them in contradiction; the proponents of other religious metaphysical conceptions believe in sources for which they possess no trace of proof for their authenticity.

The divine revelation has always been considered as the ultimate source of knowledge but it was never the sole. Muslim thinkers from the past consistently tried to acquire detailed knowledge about how to derive the rules and concepts of the Qur'an, but they developed these only on the basis of common sense instead of a unifying methodology [3].

The only approach to Qur'an should be after the priors are fulfilled:

1) The first requirement for understanding the Qur'an is to understand the Arabic language.

2) The second requirement is what we call "tafseerun-nassi bin-nass." Nass is a statement. Statement in the Qur'an must be interpreted, after we know the general Arabic meaning, by going to the Qur'an itself. Because the Qur'an - as they say in Arabic, "yufassiru ba'duhu ba'dan" - itself explains the Qur'an.

3) The third requirement for a proper understanding of the Qur'aan is the sayings, the commentaries, the explanations of the Prophet Sunnah, and after him, his Companions.

4) If there is consensus, ijmaa', that has to be taken to be the meaning of the ayah or the hadeeth of the Prophet (pbuh). There is also what is called Qiyas. Qiyas is not a means of obtaining facts directly from the Qur'an but it is a way of knowing the ruling, the "hukm", of something which is not mentioned specifically in the Qur'an. Qiyas - as the word analogy explains: We read in the Qur'an and the hadeeth that the ruling on A is B. Now, we find something $\mathrm{X}$ which is similar to A. So we say that the ruling on this $\mathrm{X}$ is also $\mathrm{B}$, because of the similarity between the two.

5) A very important requirement is sincerity. Any person, even if he is not a Muslim, he can master the language, he can read and learn by heart the ahaadeeth of the Prophet, or the verses from the Qur'an, he can know the superficial meaning of these verses, but Allah will give the real meaning, the meaning that influences a person's life and gives him hidaayah, guidance, only to someone who is sincere. 
IIUM Engineering Journal, Vol. 12, No. 5, 2011: Special Issue on Science and Ethics in Engineering

Azram

Therefore, the main sources of knowledge in Islam have to be the Qur'an and the Sunnah of the prophet (pbuh). For acquired knowledge also has to have the basis from these main sources of knowledge.

\section{TYPE OF KNOWLEDGE}

There are two main types of knowledge accepted by many Islamic scholars: revealed knowledge and derived knowledge.

\subsection{Revealed Knowledge}

The first type of knowledge, also known as al-wahy, can be further broken into two more types; the instinctive knowledge and the knowledge revealed to us through the Prophet (pbuh).

Divine revelation explicates to us two very important concepts, 'fikr' (reflection) and dhikr (contemplation/remembering). Fikr is the quest for knowledge through the ayat (signs) of Allah (SWT) while dhikr is a recollection of previously given knowledge. It is fikr that is rational and attempts to 'reach' God, i.e. the final stages of Ilm al Yaqin and Ain al Yaqin. However Dhikr, does not and cannot 'reach' God through rational methods. Therefore when we $d o$ dhikr, instead of really remembering God, we actually praise Him! In other words, we are not really recollecting the previous knowledge \{example, the covenant that Man took with Allah (SWT) \}. Rather Allah simply admonishes us to praise Him as remembering Him through the only means humans have, rationality, is not possible.

Thus in fikr, we try to 'reach' God while in dhikr we tend to praise Him rather than trying to 'reach'. It is the co-relationship between these two concepts that give us the final notion of knowledge in Islam.

"Verily in the creation of the heavens and the earth, and the alternation of night and day - there are indeed signs for men of understanding; Men who remember Allah, standing, sitting, and lying down on their sides, and contemplate the creation of the heavens and the earth (with the thought) "Our Lord! Not for nothing have You created (all) this. Glory to You! Give us salvation from the suffering of the Fire" (Q:3:190-191).

The Qur'an reminds us that we have to remember Allah all the time and thus do dhikr, while $f i k r$ has already helps Man to look for the signs of Allah.

"It is He who brought you forth from the wombs of your mother You did not know a thing, and He gave you hearing, sight, and mind in order that you may give thanks"(Q:16:78).

From this verse we can see that a baby is born without any knowledge, and it is the mercy of Allah to bestow him with fitrah.

Even the Prophet (pbuh) said in a hadeeth, "Every child is born with a pristine nature (fitrah); then his parents make him a Jew or a Christian or a Magician."

\subsection{Derived Knowledge}

The second type of knowledge is acquired knowledge. This type of knowledge is also from Allah - but Humans are supposed to use Islamic Methodology and the faculties given by Allah to acquire this knowledge. Through their senses, research and deep thinking, can 
IIUM Engineering Journal, Vol. 12, No. 5, 2011: Special Issue on Science and Ethics in Engineering Azram

they conceptualize, acquire, comprehend and search this type of knowledge. Again, the sincerity in the search is an important prior.

There are two types of Knowledge in the Qur'an. They are:

a) Ilm (knowledge) which belongs to God wherein there is no question of ' $z a n$ ' (conjecture) (Q:4:157).

b) Ilm (knowledge) which progresses from raib to yaqin.

\section{ELEMENTS OF KNOWLEDGE IN ISLAM}

The topic of discussion here is the elements of knowledge in Islam. A question that could spout in one's mind would be, "Are the elements of knowledge in Islam essentially different from other disciplines of knowledge?" Many scholars have answered this question according to their own specific perceptions. We have scholars like Ibn Rushd (or Averroes) most prominently, followed by Ibn Sina (or Avicenna) and also Al Farabi. These scholars adamantly believed that scientific thought and the Qur'anic revelation were essentially synonymous due to many inherent common qualities like reason. This concept of Reason itself had emanated from Aristotle and these scholars desperately attempted to reconcile both Reason and Revelation. It could perhaps be better understood in the word of Sarton:

"The whole history of medieval thought, in almost every part of the world, is dominated by a continuous and desperate endeavor to reconcile the facts of rational experience with some system of knowledge (revelation) considered a priori as perfect and unimpeachable." [4]

However we have many Muslim scholars who had taken the bold step of moving against this strong wind of modern thought. The first and foremost is Ghazali. Ghazali was the first among the contemporary scholars of his time to be skeptical of the infallibility of sense perception and therefore rested his philosophy on principles that were intuitively certain [5]. He freed himself of 'taqlid' (acceptance without proof) and rejected the authority of human teachers. According to him, "to attain to knowledge of the realities of things it is indispensable to ascertain what knowledge means"[6]. Thus he began to place science, philosophy and reason in position inferior to religion and theology, an approach which was happily accepted by the scholastics. He then managed to create such a culture, that medieval philosophy almost completely transformed itself to what Gazalli had propounded though Ibn Rushd still persistently adhered to his belief and even wrote a critique on Al Ghazali, 'Tahafut al-Tahafut'(Incoherence of Incoherence).

Another scholar in the later times was Muhammad Iqbal, who agreed to Ghazalli's notion and rejected the philosophy of Ibn Rushd. He says:

"Ghazali's chief opponent, Ibn Rushd who defended Greek philosophy against the rebels, was led through Aristotle to what is known as the doctrine of immortality of active intellect, a doctrine which once wielded enormous influence on the intellectual life of France and Italy, but which to my mind, is entirely opposed to the view that the Qur'an takes of the value of destiny of the human ego. This Ibn Rushd lost sight of a great and faithful idea in Islam and unwatingly helped the growth of what enervating philosophy of life obscure man's vision of himself, his God and his world.[7]" 
We have seen the views of some of the scholars of Islam on the theory of knowledge in Islam. Comprehending what the term 'knowledge' means in Islam, and understanding the 'theory of knowledge in Islam', we can now proceed to the final part of this article, the principles that make up the theology of Islam.

\section{BASIC PRINCIPLES OF KNOWLEDGE}

\subsection{Unity of Allah (Tawhid)}

This is the first and foremost principle. This principle states that Allah (SWT) is the only creator of everything and that $\mathrm{He}$ is Absolutely One, and that everything is separate and different from Him as a Creator. It is therefore the duty of a Muslim to give Allah (SWT) His Due recognition, love and obedience. Hence it becomes incumbent upon a Muslim to have Allah (SWT) constantly present in one's consciousness. Thus The Qur'an says that true Muslims are those who:

...Who celebrate the Praises of Allah, standing, sitting, and lying down on their sides and contemplate the (wonders of) creation in the heavens and the earth, (with the thought) "Our Lord! Not for naught Has Thou created (all) this Glory to Thee! Give us Salvation from the Penalty of Fire. $(Q: 3: 191)$

It is necessary therefore to accept the authority of Allah (SWT). In cases where this authority is not conceded, the following problems result that make man incapable of searching knowledge and understanding knowledge:

a) Lack of faith:

This puts a veil in front of our eyes and we become incapable of understanding the message of the Qur'an as we do not believe in Allah (SWT):

"Say: consider what is in the heavens and the earth; and signs and warners do not avail people who would not believe." (Q:10:101)

b) Blind imitation:

This puts blinkers on their eyes and they begin to see the path which has been shown to them by parents and the people in power.

"And they shall say: O our Lord! Surely we obeyed our leaders and our great men, so they led us astray from the path.” (Q:33:67)

c) Superstitions:

When we believe that Allah (swt) is the sole creator of everything and thus begin to follow his commands, we are saved from baseless superstitions.

"And they have no knowledge of it; they do not follow anything but conjecture (zan), and sure conjecture does not avail against the truth at all.” (Q:53:28)

\subsection{Unity of Creation}

When we believe that there in the concept of Unity of God, then quite logically we should also believe that there should be unity in His creation. Khalil has noted this point very well and explains:

"It is self-evident that the Qur'anic and scientific data should coincide and correspond (in the general sense and outside the realm of relativities and variables), and it is obvious that there should be no contradictions or barriers between them." 
Natural or Pure science is basically the study of the creation of God. Khalil has succinctly expounded the relationship of science with Quran. He says that there are basically four main categories. The first is about the philosophy of science and the theory of knowledge. The second category facilitates us with the methodology of discovering scientific facts. The third informs us of the laws that apply in the various fields of science, i.e. the creation (natural or pure science) while the fourth admonishes us that those laws that have been discovered through experimental methodology should be applied by a Muslim as a vicegerent of Allah (swt) to create a just society. He calls this field, the applied sciences. According to him therefore, we should use these scientific laws created by Allah (swt) for creating a civilization where people comply with the commandments of Allah (swt) and therefore are able to live in a just and peaceful society.

I would like to discuss here the notion of causality as it is linked directly to the concept of unity of creation. To put it succinctly, this concept states that everything has a cause. There are two basic fundamentals attached to this principle:

a) The principle of determinism - every cause has an effect and that without a cause it is impossible to have an effect.

b) The principle of uniformity of nature: similar causes ensue similar effects.

There is an assumption that has been going on for a very long time. According to many scientists there are certain laws that are governing our physical universe. The principle of causality gives meaning to the application of any law used to explain natural phenomenon.

There are many instances in the Qur'an that speak about this too:

"Then should they wait for aught except the way of the former people? For you shall not find any alternation in the Course of Allah." (Q:3:43)

Another verse that is in consonance to the concept of causality is:

"The nature made by Allah in which He has made men; there is no altering of Allah's creation" (Q:30:30)

However some Asharite scholars like Al-Ghazali and Al-Razi, believe that adhering to this concept would imply that Allah (SWT) is dependent on the causality factor. There are again other scholars who have accepted this concept of causality like Faruqi. He observes that:

"The causal and finalistic interconnections of the objects of creation are the substance of the subservience, which would be futile and meaningless without them. If man could not depend upon causes to bring about their effects or the means not to be good for the ends, he would quickly lose interest in creation and give up any attempt to transform it into the ought - patterns revealed by Allah (SWT)[8]".

Contemplating at both views critically, the notion of Faruqi is more feasible. This is because the causality concept itself can be considered a creation of Allah (SWT). There is a reason behind every creation of Allah (SWT). Here we could assume that Allah (SWT) has created this causality factor to act as a stimulant to man so that he can work to achieve means.

Golshani has explicated this concept very well:

"...what is commonly called a cause is implying an intermediary or preparing cause, rather than the efficient cause" The role of intermediary means I to prepare the ground for the creation of everything, but $\mathrm{He}$ creates everything through definite intermediary and preparing causes, and these are themselves created by Allah (SWT)"'[9].

\subsection{Unity of Thought (Revelation and Reason)}


We had seen above that when the Source of Science and Qur'an are the same, they cannot logically contradict each other. The same is veracious for Revelation and Reason. Revelation is by Allah (SWT) and reason, just like causality, is created by Allah (swt) to act a stimulant for man. Al Ghazali had also subscribed to this comprehension when he spoke of the 'division in knowledge'. According to him, in the categorization of knowledge, Shari (which depends ultimately on revelation) and Aqli (which depends on reason), are not really in themselves distinct. In his words, “...most shari knowledge is Aqli to him who know it and most Aqli knowledge is Shari to him who understands it [10].

It is quite evident that Revelation and Reason share inherent qualities. However it would be incorrect to say that both are exactly the same. This is because Reason is just based on the zahir (what can be seen). However the Qur'an is replete with verses that speak about the many physical phenomena that man is unable to see:

"But nay! I swear by that which you see, and that which you do not see”. (Q:69:38-39)

"He created the heavens without pillars as you see the..."(Q:31:10)

This is where the drawbacks of reason commence. It is unable to see and therefore perceive many physical phenomena. In other words, reason on its own is based on incomplete empirical data. Thus the conclusions it makes on its own cannot be guaranteed to be correct. Thus, Faruqi rightly concludes that:

"Reason will be well balanced only when it submits to the guidance of revelation as to the ultimate aim of existence" [11].

To put it succinctly, we acknowledge the limitation of human mind. Therefore we do not only want to make use of the human invention system, Trial and Error.

\subsection{Unity of Man}

Allah (SWT) had created Adam (ra) and taught him the "name of things". Then Allah (SWT) ordered all the angel to prostrate before Adam (ra) when they could not say the name of things which He had taught to Adam (ra). An interesting point that Qadir notes here is that the angels were asked to prostrate to Adam (ra) due to the superiority Adam's wisdom and not his piety. It is obvious that in terms of piety, the Angel eclipsed Adam. However, Allah (SWT) still commanded them to prostrate before Adam due to his superiority of knowledge [12]. This not only reveals the importance of knowledge, but also the great responsibility.

Man has been placed in this world as a vicegerent of Allah (SWT). Therefore it becomes his duty to make use of this knowledge as one of the means to achieve his ends, both physical and spiritual. Khalil has therefore rightly observed that:

"Muslims cannot carry out their functions as vicegerents, or obtain sufficient guarantees and assistance to enable them to achieve their objectives of perpetual progress unless they use scientific research methods and methodologies to discover the laws of the world, nature, and the cosmic system."

It would be futile to speak on this unless a very prominent scholar of Islam, Faruqi's integrated view on man, knowledge and his purpose of life are not comprehended:

"Islam's view of man. Allah (SWT) has appointed him to achieve two objectives. First, humans should transform creation into Divine patterns, i.e., to rearrange its materials so as to make them fully and beneficially serve human needs, which are materials( food, shelter, comfort, procreation) as well as moral intellectual, and esthetic. Second, in the very act of transforming creation, humans need to give substance to ethical values by choosing to enter 
IIUM Engineering Journal, Vol. 12, No. 5, 2011: Special Issue on Science and Ethics in Engineering Azram

into those acts of transformation in an ethical way, i.e., in a way that fulfills the requirements of devotion to Allah (SWT) and justice to mankind"'13].

\section{LIMITATIONS OF HUMAN KNOWLEDGE}

Even though seeking knowledge is considered on of the basic steps towards understanding Allah, humans are incapable of perceiving some knowledge which is unseen or cannot be perceived with our limited senses. As Allah states in the Qur'an:

"I swear by what you see and what you do not see..."(Q:69:38-39)

"Glory be to Him Who created pairs of all things, of what the earth grows, and of their kind and of what they do not know..."(Q:36:36)

The faith in the limitation of human knowledge and the unseen is an incentive for us not to stop our mind at the sensory stage and never think that we have discovered everything [14]. The quest of knowledge is endless for a Muslim, and he must be sincere. He must just not fall out of the unique methodology of acquiring knowledge or understanding the divine scriptures; the Holy Qur'an.

\section{CONCLUSION}

In Islam 'ilm is not confined to the acquisition of knowledge only, but also embraces socio-political and moral aspects. Knowledge is not mere information; it requires the believers to act upon their beliefs and commit themselves to the goals which Islam aims at attaining. In brief, the theory of knowledge in the Islamic perspective is not just epistemology. It combines knowledge, insight, and social action as its ingredients.

The main sources of knowledge for Muslims will eternally be Qur'an and the Sunnah. If we hold on to these two sources of knowledge, we will not fall prey to any unislamic activity.

Understanding the different types of knowledge and the principles behind the theory of knowledge will remain the basis of Islamic philosophy. Thus before going through any type of knowledge we must begin with Unity of Allah that leads us quite logically to the Unity of His creation. The Unity of Allah and His creation form the fundamentals for the basis of thought that should be in Islam. This is called the Unity of Thought. All these principles provide the aim and purpose of life for man-vicegerency (khilafa). This is the principle of Unity of Man.

Since Man is the khalifa, it becomes incumbent upon him to mould knowledge in the framework provided by Islam. Thus all types of knowledge whether it is Natural Science, Social Science or even Pure Science, should be understood with the aim to establish an Islamic System. The understanding of these sciences is done with the help of the principle expounded above that form the basis of the theory of knowledge in Islam.

\section{REFERENCES}

[1] E. Cooper, David, Epistemology The classic Readings, University of Durham, (USA,1999), p. 1

[2] Akhtar, Dr. Sayyid Wahid, Al-Tawhid The Islamic Concept of Knowledge, Vol XIII No.3, (Dubai ,2001) 
IIUM Engineering Journal, Vol. 12, No. 5, 2011: Special Issue on Science and Ethics in Engineering

[3] Safi, Louai, The Foundation of knowledge: A Comparative Study in Islamic and Western Methods of Inquiry, Selangor Darul Ehsan, Malaysia, International Islamic University and International Institute of Islamic Thought, Malaysia, 1996, pp. 180-182

[4] G. Sarton, Inroduction to the History of Science, 3 vols, (New York, 1997).

[5] W. Montgomery Watt, The faith and practice of al- Ghazali (London, Allen and Unwin, 1953), p. 12

[6] W.R.W. Gardener, Al Ghazali , (Madras : Christian Literature Society for India, 1919) p. 33.

[7] Iqbal, Muhammad, The Reconstruction of Islamic Religious Thought in Islam, (Lahore: Sh. Muhammad Ashraf, 1982) pp. 149-150

[8] Ismail R. al Faruqi, Islamization of Knowledge : General Principles and Work Plan (Herndon, VA : IIIT, 1987), p. 39

[9] Mehdi Golshani, "Philosophy of Science from the Qur'anic Perspective", Towrds Islamization of Disciplines. IIIT, Washington D.C, 1989 pp. 73-92

[10] Al Ghazali, al Risalah al Laduniyyah, $2^{\text {nd }}$ editin, (Cairo: Matba' ah as Sadah, 1342, A.H.) p. 32

[11] Ismail R. al Faruqi, Islamization of Knowledge : General Principles and Work Plan (Herndon, VA : IIIT, 1987), p. 52

[12] Qadir, C. A., Philosophy and Science in the Islamic World, USA, 1988, Croom Helm, p. 6

[13] Ismail R. al Faruqi, Islamization of Knowledge : General Principles and Work Plan (Herndon, VA : IIIT, 1987), p. 44

[14] Mehdi Golshani, "Philosophy of cience from the Qur' anic Perspective", Towrds Islamization of Disciplines. IIIT, Washington D.C, 1989 p. 84 